\title{
Improved sulphate removal rates at increased sulphide concentration in the sulphidogenic bioreactor
}

\author{
HA Greben ${ }^{1 *}$, JP Maree', E Eloff ${ }^{1}$ and K Murray ${ }^{2}$ \\ ${ }^{1}$ Division of Water, Environment and Forestry Technology, CSIR, PO Box 395, 0001 Pretoria \\ ${ }^{2}$ Insight Modelling Services, Pretoria, South Africa
}

\begin{abstract}
The product of the biological sulphate reduction is sulphide. High concentrations of molecular $\mathrm{H}_{2} \mathrm{~S}(\mathrm{~g})$ can be inhibitory for microbial activity, especially at a reactor $\mathrm{pH}$ of 6 to 7 . This paper focuses on the effect of high sulphide concentrations on the sulphate reduction rates. The results of three investigations operating a continuous reactor, a column reactor and batchtest reactors have shown that increased sulphide concentrations have resulted in improved biological sulphate reduction. In all instances the reactor $\mathrm{pH}$ was kept at 7.5 to 8.5 . It was shown that when the sulphide concentration was $700 \mathrm{mg} / \ell$ in a continuously operated reactor, the sulphate reduction rate was $12 \mathrm{gSO}_{4} / \ell \cdot \mathrm{d}$. When operating batch-test reactors the results showed that when the sulphide concentration increased, to $1400 \mathrm{mg} / \ell$, the volumetric and specific sulphate reduction rates correspondingly increased to $4.9 \mathrm{gSO}_{4} / \ell \cdot \mathrm{d}$ and $1.5 \mathrm{gSO}_{4} / \mathrm{gVSS}$, respectively. Thirdly, operating a tall column reactor using $\mathrm{H}_{2}$ and $\mathrm{CO}_{2}$ as the energy source, showed that when the initial sulphide concentration of the feed water was 0,100 and $268 \mathrm{mg} / \ell$, the average biological sulphate removals were 650,1275 and $1475 \mathrm{mg} / \ell$, respectively. These obtained results indicated that the addition of sulphide to the feed water to the reactor had a positive effect on sulphate removal. Improved sulphate removal results in increased alkalinity production and in an increased reactor $\mathrm{pH}$, which in turn is favourable for a decrease in the redox potential, when a dominant redox couple, like sulphate: sulphide, is present in a reactor.
\end{abstract}

Keywords: alkalinity, pH, Redox value, sulphate reduction rate, sulphide toxicity

\section{Introduction}

Acid mine drainage (AMD) is the result of mining activities, due to bacterial oxidation and exposure to oxygen and water of sulphide minerals (pyrite) by a group of acidophilic iron reducing micro organisms. Because of the salinisation properties of AMD and the associated scaling and bio- corrosion problems, as well as increased environmental awareness among the general population, methods are being investigated to remove the high sulphate concentration of AMD. Sulphate-rich effluents can be treated biologically when sulphate reducing bacteria (SRB) and organic matter are present. The products of the biological sulphate removal technology are sulphide and alkalinity, which contribute to the $\mathrm{pH}$ increase of the treated water. The advantage of the sulphide formation is that the metals present in the AMD precipitate as metal-sulphide (MeS). The disadvantage of the formation of hydrogen sulphide is its toxicity for both the methanogenic activity of granular sludge (Koster et al., 1986) as well for the sulphidogenic bacteria, e.g. Desulfovibrio desulfuricans (Okabe et al., 1995). Moreover, it has been reported that the produced sulphides are fatally toxic to humans at gaseous concentrations of 800 to $1000 \mathrm{mg} / \ell$ (Speece, 1996). Because of its toxicity, it is forbidden in most industrialised countries to drain sulphide-containing effluents into sewer pipes or surface waters (Janssen, 1996). When no metals are present, sulphide accumulation can result in a severe inhibition of the purification process and in some cases might even cause total process failure. Many studies have been dedicated to the effect of sulphide toxicity on the biological sulphate reduction efficiency. In gen-

\footnotetext{
* To whom all correspondence should be addressed.

용 +2712 841-2278; fax + 27 ; fax: +2712 8412506 ;

e-mail: hgreben@csir.co.za

Received 19 November 2004; accepted in revised form 23 March 2005.
}

eral, these studies demonstrated that, under mesophilic conditions, both granular and suspended sludge are more tolerant to sulphide inhibition at a $\mathrm{pH}$ of around 8 , when the sulphide is in the $\mathrm{HS}^{-}$form. At neutral $\mathrm{pH}$ values, free $\mathrm{H}_{2} \mathrm{~S}$ (sulphide in gas form), which is more toxic than HS, accounts for $50 \%$ of total dissolved sulphide, whereas at $\mathrm{pH} 8$ it is only around $10 \%$ (Lens and Hulshoff Pol, 2000). Speece (1996) listed the sulphide toxicity levels investigated by different researchers, which showed that 100 to $150 \mathrm{mg} / \ell$ sulphide is toxic for lactate- and glucoseutilising SRB in a continuously stirred tank reactor (CSTR). Moreover, 60 to $75 \mathrm{mg} / \ell$ sulphide was not tolerated by acetateand propionate-utilising SRB (in a CSTR), while Parkin et al. (1990) reported that when the sulphide concentration was 60 to $70 \mathrm{mg} / \ell$, in an acetate- and propionate-fed chemostat, it resulted in process failure.

The aim of this investigation was to demonstrate that high sulphide concentrations ( 700 to $1400 \mathrm{mg} / \ell$ ) in the biological sulphidogenic reactor can be beneficial for biological sulphate removal, operating:

- A completely mixed demonstration reactor

- A tall column reactor

- Four small-scale laboratory test reactors.

\section{Materials and methods}

\section{Operating a pilot-scale completely-mixed biological} sulphate removal reactor

\section{Feed water}

The feed water to the sulphate removing reactor consisted of AMD of which the composition is given in Table 1. It was supplemented with macronutrients $(25 \mathrm{mg} / \ell$ ammonia- $\mathrm{N}$ and 


\begin{tabular}{|l|c|l|c|}
\hline \multicolumn{4}{|c|}{ TABLE 1 } \\
Chemical composition of the feed water (AMD) for the demo-scale plant \\
\hline Parameter & $\begin{array}{c}\text { Composition } \\
\text { AMD }\end{array}$ & Parameter & $\begin{array}{c}\text { Composition } \\
\text { AMD }\end{array}$ \\
\hline $\mathrm{pH}$ & 6.5 & Magnesium $(\mathrm{mg} / \ell \mathrm{Mg})$ & 101 \\
\hline $\mathrm{Sulphate}\left(\mathrm{mg} / \ell \mathrm{SO}_{4}\right)$ & 2316 & Iron $(\mathrm{mg} / \ell \mathrm{Fe})$ & 2.5 \\
\hline $\mathrm{COD}\left(\mathrm{mg} / \ell \mathrm{O}_{2}\right)$ & 1657 & Aluminium $(\mathrm{mg} / \ell \mathrm{Al})$ & 0.34 \\
\hline Chloride $(\mathrm{mg} / \ell \mathrm{Cl})$ & 142 & Manganese $(\mathrm{mg} / \ell \mathrm{Mn})$ & 2.8 \\
\hline Sulphide $(\mathrm{mg} / \ell \mathrm{S})$ & 0 & Sodium $(\mathrm{mg} / \ell \mathrm{Na})$ & 40 \\
\hline Alkalinity $(\mathrm{mg} / \ell)\left(\mathrm{CaCO}_{3}\right)$ & 50 & Total dissolved solids $(\mathrm{mg} / \ell)$ & 4117 \\
\hline Calcium $(\mathrm{mg} / \ell \mathrm{Ca})$ & 957 & Temperature $\left({ }^{\circ} \mathrm{C}\right)$ & 23 \\
\hline
\end{tabular}

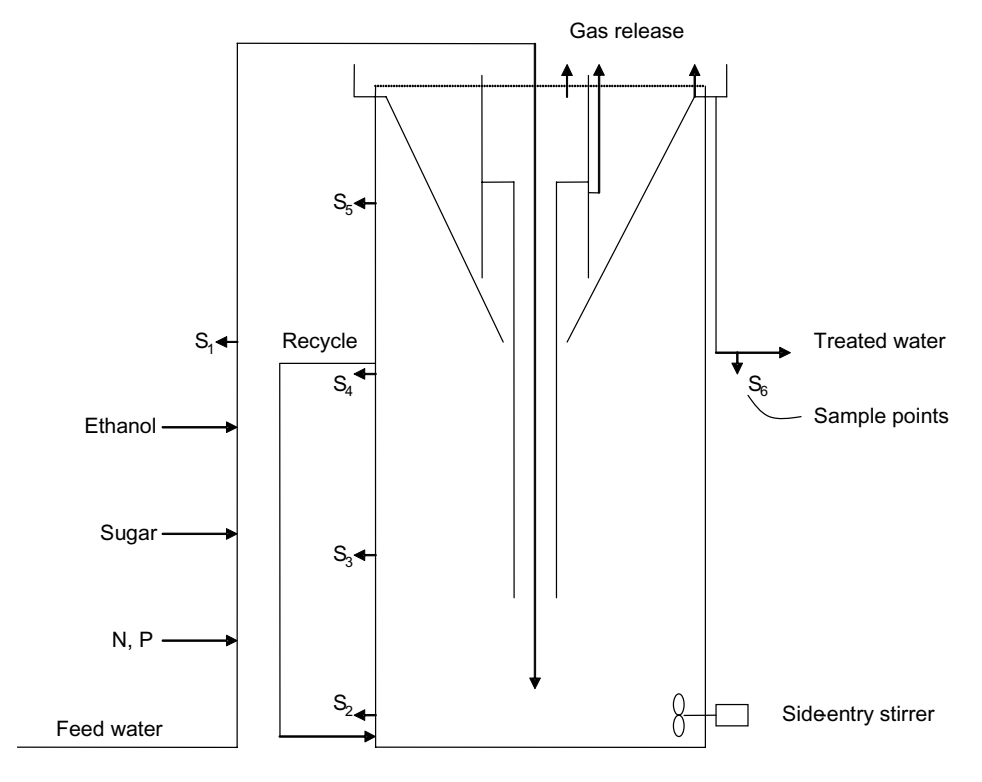

from the Daspoort Sewage Treatment Plant, Pretoria. With time, this sludge became sulphate-adapted biomass with a large active population of SRB.

\section{Experimental}

\section{CSIRosure}

The experimental conditions of the continuously stirred reactor are given in Table 2.

\begin{tabular}{|l|c|c|}
\hline \multicolumn{3}{|c|}{ TABLE 2} \\
$\begin{array}{c}\text { The experimental conditions op- } \\
\text { erating the pilot scale reactor }\end{array}$ \\
\hline Period (d) & $\begin{array}{c}\text { Feed rate } \\
\left(\mathbf{m}^{3}\right) / \mathbf{h}\end{array}$ & HRT $(\mathbf{h})$ \\
\hline $1-192$ & 8 & 10.2 \\
\hline $193-202$ & 12 & 6.8 \\
\hline $203-205$ & 8 & 10.2 \\
\hline $206-207$ & 14 & 5.9 \\
\hline $208-219$ & 16 & 5.1 \\
\hline
\end{tabular}

Figure 1

Schematic diagram of the anaerobic reactor

$5 \mathrm{mg} / \ell$ ortho-phosphate-P) and $3 \mathrm{mg} / \ell \mathrm{Fe}$ as the only micronutrient, since the feed (mine) water contained all trace elements required by the SRB. Sodium bicarbonate was added to maintain a $\mathrm{pH}$ of higher than 7.0. This procedure was terminated once sufficient alkalinity was generated from sulphate reduction. A mixture of ethanol $(1.5 \mathrm{~m} \ell$ ethanol $/ \ell$ feed $)$ and sugar $(0.25 \mathrm{~g}$ sugar $/ \ell$ feed $)$ was used as the carbon and energy source (Greben et al., 2002). Sugar is degraded by the fermenting bacteria to volatile fatty acids (VFA) and hydrogen $\left(\mathrm{H}_{2}\right)$, which the SRB can use as the energy sources.

\section{Reactor}

The pilot-scale reactor system, CSIRosure, which was operated at Navigation Mine, Witbank, SA, consisted of a fibre-glass cylindrical reactor, with a built in cone shaped clarifier (Fig. 1). The volume of this reactor was $105.5 \mathrm{~m}^{3}$. The reactor was a completely mixed reactor system, fitted with a side-entry stirrer $(260 \mathrm{r} / \mathrm{min})$, positioned at the bottom of the reactor. The feed entered the reactor through a feed inlet pipe from the top to the bottom of the reactor and a recycle stream was in place from just above Sample Port S4 (Fig.1) to the bottom of the reactor. Complete mixing occurred in the reactor when the particles, entering the reactor through the feed pipe were dispersed immediately throughout the reactor due to the side entry stirrer as shown in Fig. 1. The reactor, which was operated at the ambient temperature of 20 to $25^{\circ} \mathrm{C}$, was inoculated with $10 \mathrm{~m}^{3}$ anaerobic digester sludge

\section{Operating a tall column reactor fitted with a venturi for optimal gas/liquid distribution for biological sulphate removal}

\section{Feed water}

The artificial feed water, used for the venturi reactor, contained $3.9 \mathrm{~g} / \ell \mathrm{MgSO}_{4} .7 \mathrm{H}_{2} \mathrm{O}$ so that the $\mathrm{SO}_{4}$ concentration was $\approx 1700$ $\mathrm{mg} / \ell$. The nutrients $\mathrm{P}$ and $\mathrm{N}$ were added as $50 \mathrm{mg} / \ell \mathrm{H}_{3} \mathrm{PO}_{4}$ and $200 \mathrm{mg} / \ell\left(\mathrm{NH}_{4}\right)_{2} \mathrm{SO} 4$, respectively. Trace elements were added as $2 \mathrm{mg} / \ell \mathrm{FeSO}_{4}$ and $1 \mathrm{~m} \ell / \ell$ of $\mathrm{KCl}, \mathrm{FeCl}_{3} \cdot 4 \mathrm{H}_{2} \mathrm{O}, \mathrm{NiNO}_{3} \cdot 6 \mathrm{H}_{2} \mathrm{O}$, $\mathrm{CoCl}_{2} \cdot 6 \mathrm{H}_{2} \mathrm{O}$ (all $1 \mathrm{mg} / \ell$ ) and $\mathrm{MnCl}_{2} \cdot 4 \mathrm{H}_{2} \mathrm{O}, \mathrm{ZnCl}_{2}, \mathrm{Na}_{2} \mathrm{MoO}$, $\mathrm{H}_{3} \mathrm{BO}_{3}$ and $\mathrm{CuCl}_{2} \cdot 2 \mathrm{H}_{2} \mathrm{O}$ (all $1 \mu \mathrm{g} / \ell$ ). The $\mathrm{pH}$ increased when additional sulphide was added to the feed water. In order to have the same start $\mathrm{pH}$ value in all three experiments, the feed-water $\mathrm{pH}$ was corrected using $1 \mathrm{~N} \mathrm{HCl}$ to 7.4 (Table 6).

\section{Reactor}

The venturi reactor (Fig. 2) was $6 \mathrm{~m}$ tall, its total volume was 190 $\ell$ and its active volume was $157 \ell$. A gas mixture of hydrogen and carbon dioxide $\left(80 \% \mathrm{H}_{2}: 20 \% \mathrm{CO}_{2}\right)$ was used as the energy and carbon source. The gas mixture was sucked into the reactor through a venturi system, which provided small gas bubbles. The delivery rate of the gas was controlled using a Watson-Marlow pump (Watson-Marlow Bredel SA, Honeydew, Gauteng, $\mathrm{SA})$. The feed water entered the reactor from the top, while the gas was pumped into the recycle line, thereby providing optimal conditions for gas/liquid exchange. The reactor was packed with $80 \%$ geo-textile strips for biofilm formation on these strips. 


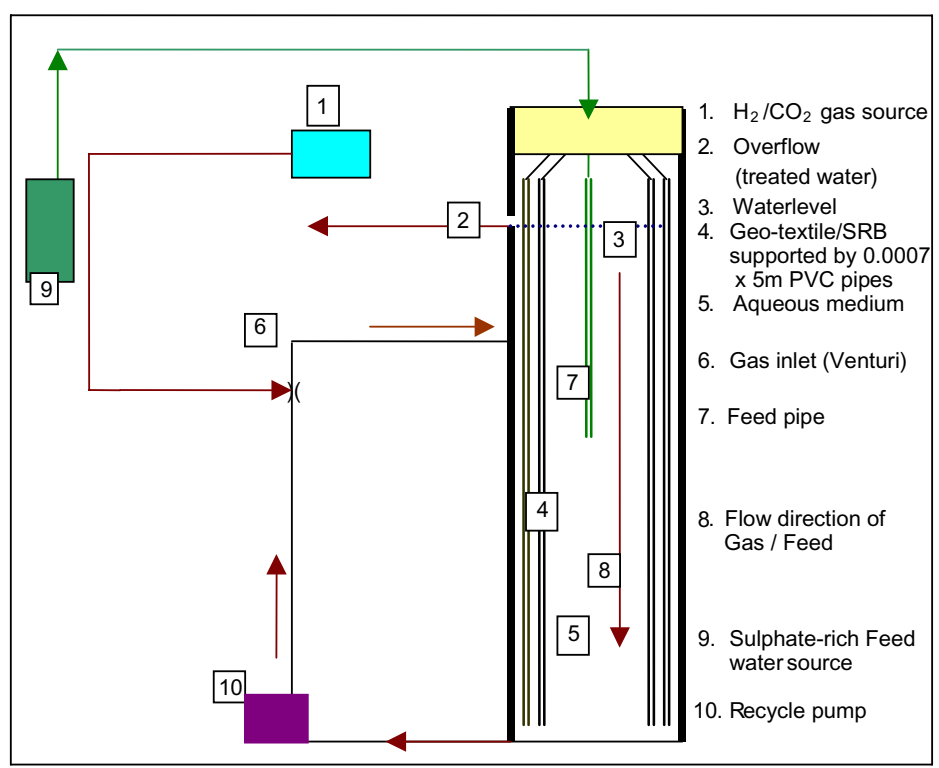

Figure 2

Schematic diagram of the venturi reactor

\section{Experimental}

The venturi reactor was operated in continuous mode until stable sulphate removal $(90 \%)$ was achieved. Thereafter the reactor was operated in batch mode, as this way of operation provided conditions for collecting kinetic data in a short period of time, while investigating the effect of different parameters on the sulphate removal rate. Batch mode operation involved draining the treated water completely from reactor, so that only the biofilm-covered geo-textile strips stayed behind in the reactor, and subsequently re-filling the reactor with fresh feed water immediately thereafter. The gas mixture volume during this investigation was $700 \mathrm{~m} \ell / \mathrm{min}\left(0.6 \mathrm{~g} / \ell \mathrm{H}_{2}\right)$, resulting in a 4.5 times the stoichiometric amount needed for total sulphate reduction per litre of feed water $(0.13 \mathrm{~g} / \ell)$. In order to investigate the effect of sulphide on the sulphate removal rate, three different studies were conducted, varying the sulphide concentration in the feed water. During the first study, no sulphide was added to the feed water (control), during the second study, the initial sulphide concentration in the feed water was $100 \mathrm{mg} / \ell$, while in the third study this was $268 \mathrm{mg} / \ell$. In both instances $\mathrm{Na}_{2} \mathrm{~S}$ was used (Merck SA, Johannesburg). Samples $(50 \mathrm{m \ell})$ were taken at regular intervals over a period of $24 \mathrm{~h}$ during each investigation.

\section{Operating four stirred laboratory batch-test reactors}

\section{Feed water and reactors}

The feed water for four stirred batch-test reactors (1 to 4), consisted of artificial feed water of which the sulphate concentration $\left(\mathrm{MgSO}_{4}\right)$ was approximately $1500 \mathrm{mg} / \ell$. The feed water was supplemented with both macro-nutrients $(75 \mathrm{mg} / \ell$ ammonia-N and 15 $\mathrm{mg} / \ell$ orthophosphate-P) and micro-nutrients $(100 \mu \mathrm{g} / \ell$ $\mathrm{Fe}, 210 \mu \mathrm{g} / \ell \mathrm{Co}, 0.28 \mu \mathrm{g} / \ell \mathrm{Mn}, 0.44 \mu \mathrm{g} / \ell \mathrm{V}, 0.25 \mu \mathrm{g} / \ell$ $\mathrm{Ni}, 0.48 \mu \mathrm{g} / \ell \mathrm{Zn}, 0.40 \mu \mathrm{g} / \ell \mathrm{Mo}, 0.18 \mu \mathrm{g} / \ell \mathrm{B}, 0.37 \mu \mathrm{g} / \ell$ $\mathrm{Cu}$ ). The carbon and energy source added to the feed water was a mixture of ethanol $(1.5 \mathrm{~m} \ell / \ell)$ and sugar $(0.25 \mathrm{~g} / \ell)$, such that the COD: $\mathrm{SO}_{4}$ ratio was $1: 1$. Glass bottle reactors 1 to 4 (volume $2 \ell$ ) were operated under anaerobic conditions. The reactors received sulphateadapted biomass, obtained from the CSIRosure reactor. Samples $(50 \mathrm{~m} \ell)$ were taken daily from the bottom of the reactor. The experiments were carried out at room temperature $\left(20\right.$ to $\left.25^{\circ} \mathrm{C}\right)$.

\section{Experimental}

The experimental conditions operating Reactors 1 to 4 are given in Table 3. The following information can be observed from Table 3:

- Day 1: The conditions in all 4 reactors were the same.

- Day 2: After sample-taking, the contents of Reactors 1 to 3 were disposed of and these reactors received new biomass (250 $\mathrm{m} \ell$ ) and $1750 \mathrm{~m} \ell$ fresh feed water. Therefore the conditions in Reactors 1 to 3 on Day 2 were identical to those in Reactors 1 to 4 on Day 1. Reactor 4: After sample-taking $(50 \mathrm{~m} \ell)$, fresh $\mathrm{MgSO}_{4}$ as a powder was dissolved in $50 \mathrm{~m} \ell$ tap water (to replace the volume taken for the sample) and added to the contents of Reactor 4, such that the start $\mathrm{SO}_{4}$ concentration on Day 2 was $1500 \mathrm{mg} / \ell$. Sulphide-rich water was produced in Reactor 4 on Day 1, which remained in the reactor. Therefore on Day 2, Reactor 4 contained an increased sulphide concentration compared to Reactors 1 to 3 .

- Day 3: The procedures as described for Day 2 were repeated for Reactors 1 and 2, so that the conditions in Reactors 1 and 2 were the same and identical to all four reactors on

\begin{tabular}{|c|c|c|c|c|}
\hline \multicolumn{5}{|c|}{$\begin{array}{c}\text { TABLE } 3 \\
\text { The experimental conditions for the batch test }\end{array}$} \\
\hline \multirow[t]{2}{*}{ Period } & \multicolumn{4}{|c|}{$\begin{array}{ll}\text { Reactors } \\
\end{array}$} \\
\hline & 1 & 2 & 3 & 4 \\
\hline Day 1 & $\begin{array}{l}1750 \mathrm{~m} \ell \text { feed } \\
250 \mathrm{~m} \ell \text { biomass }\end{array}$ & $\begin{array}{l}1750 \mathrm{~m} \ell \text { feed } \\
250 \mathrm{~m} \ell \text { biomass }\end{array}$ & $\begin{array}{l}1750 \mathrm{~m} \ell \text { feed } \\
250 \mathrm{~m} \ell \text { biomass }\end{array}$ & $\begin{array}{l}1750 \mathrm{~m} \ell \text { feed } \\
250 \mathrm{~m} \ell \text { biomass }\end{array}$ \\
\hline Day 2 & $\begin{array}{l}1750 \mathrm{~m} \ell \text { feed } \\
250 \mathrm{~m} \ell \text { biomass** }\end{array}$ & $\begin{array}{l}1750 \mathrm{~m} \ell \text { feed } \\
250 \mathrm{~m} \ell \\
\text { biomass } * *\end{array}$ & $\begin{array}{l}1750 \mathrm{~m} \ell \text { feed } \\
250 \mathrm{~m} \ell \text { biomass** }\end{array}$ & Fresh $\mathrm{SO}_{4}$ feed* \\
\hline Day 3 & \begin{tabular}{|l|}
$1750 \mathrm{~m} \ell$ feed \\
$250 \mathrm{~m} \ell$ biomass \\
\end{tabular} & \begin{tabular}{|l|}
$1750 \mathrm{~m} \ell$ feed \\
$250 \mathrm{~m} \ell$ biomass $* *$ \\
\end{tabular} & Fresh $\mathrm{SO}_{4}$ feed* & Fresh $\mathrm{SO}_{4}$ feed* \\
\hline Day 4 & \begin{tabular}{|l|}
$1750 \mathrm{~m} \ell$ feed \\
$250 \mathrm{~m} \ell$ biomass**
\end{tabular} & Fresh $\mathrm{SO}_{4}$ feed* & Fresh $\mathrm{SO}_{4}$ feed* & Fresh $\mathrm{SO}_{4}$ feed* \\
\hline Day 5 & Fresh $\mathrm{SO}_{4}$ feed* & Fresh $\mathrm{SO}_{4}$ feed* & Fresh $\mathrm{SO}_{4}$ feed* & Fresh $\mathrm{SO}_{4}$ feed* \\
\hline
\end{tabular}


TABLE 4

The VSS (mg/l) concentration and the $\mathrm{pH}$ (units) in the reactors at the start of each day

\begin{tabular}{|l|c|c|c|c|c|c|c|c|}
\hline \multirow{2}{*}{ Day } & \multicolumn{2}{|c|}{$\mathbf{2}$} & \multicolumn{2}{c|}{$\mathbf{2}$} & \multicolumn{2}{c|}{$\mathbf{3}$} & \multicolumn{2}{c|}{$\mathbf{4}$} \\
\cline { 2 - 9 } & VSS & $\mathbf{p H}$ & VSS & $\mathbf{p H}$ & VSS & $\mathbf{p H}$ & VSS & $\mathbf{p H}$ \\
\hline 1 & 4004 & 7.82 & 3268 & 8.31 & 4044 & 8.01 & 3788 & 7.64 \\
\hline 2 & 4860 & 8.12 & 5316 & 8.09 & 5124 & 8.08 & 3408 & 7.59 \\
\hline 3 & 6908 & 8.23 & 3636 & 8.16 & 4652 & 7.75 & 3268 & 7.55 \\
\hline 4 & 7788 & 8 & 4488 & 7.94 & 3652 & 7.83 & 2916 & 7.44 \\
\hline 5 & 4892 & 8.16 & 2656 & 7.96 & 2720 & 7.69 & 2320 & 7.38 \\
\hline
\end{tabular}

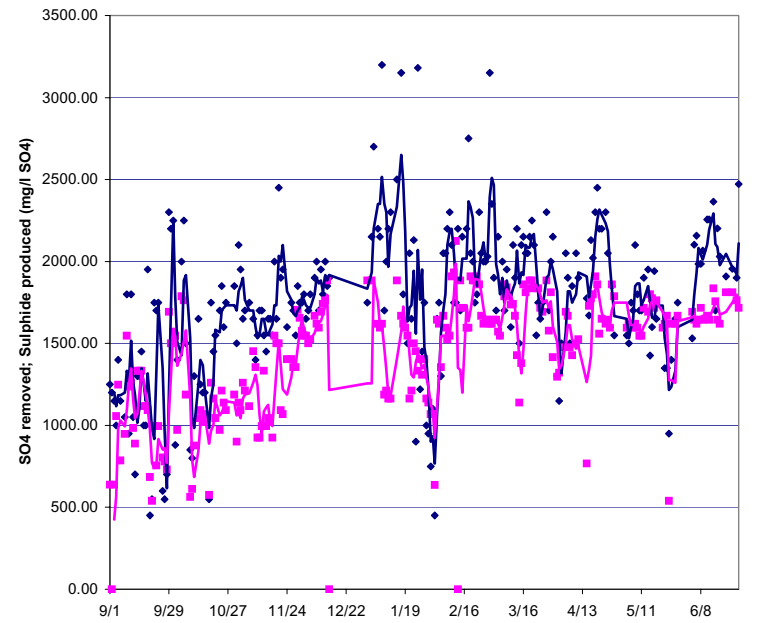

Day 1. The procedures as described for Reactor 4 on Day 2 were repeated for Reactors 3 and 4 on Day 3 and thus Reactor 3 had sulphide rich water, while Reactor 4 contained higher concentration sulphide- rich water.

- Day 4: The same procedures as for Reactors 1 to 3 on Day 2 were repeated for Reactor 1, thus the conditions in Reactor 1 were the same as those in all four reactors on Day 1 . The same procedure as for Reactor 4 was repeated for Reactors 2, 3 and 4, therefore these reactors contained sulphide-rich water: The sulphide concentration in R $4>$ in R $3>$ in R 2 .

- Day 5: All 4 reactors were similarly treated as Reactor 4 on Day 2 and thus all reactors received the same fresh $\mathrm{SO}_{4}$ feed $\left(\mathrm{MgSO}_{4}\right.$ as the chemical, dissolved in $50 \mathrm{~m} \ell$ water) and all 4 reactors contained sulphide-rich feed: The sulphide concentration in $\mathrm{R} 4>$ in $\mathrm{R} 3>$ in $\mathrm{R} 2>$ in $\mathrm{R} 1$.

The reactor $\mathrm{pH}$ and the VSS concentrations during the batch test are given in Table 4. It can be observed that the reactor $\mathrm{pH}$ mainly ranged between $\mathrm{pH}$ of 7.5 to 8.5 .

Although the conditions in all four reactors were the same on Dayl, it can be noted that the VSS values differed slightly, varying from 3.2 to $4.0 \mathrm{~g} / \ell$. From Day 2 to 5 , the VSS concentration in R4 decreased slowly, because biomass was lost during sample taking while no new biomass was added. On Day 2 the VSS values in Reactors 1 to 3 were similar. From Day 2 onwards the VSS concentration decreased in R3, for the same reason as in R4. The lower VSS concentration in the reactors will result in lower volumetric sulphate reduction reaction rates, while the specific sulphate reduction rate is a function of the VSS (biomass) concentration.

\section{Analytical}

Determinations of sulphate, sulphide, COD, $\mathrm{pH}$, mixed liquor suspended solids (MLSS) and volatile suspended solids (VSS) were carried out according to standard analytical procedures as described in Standard Methods, 1985. The redox potential of the samples was calculated from the $\mathrm{mV}$ and stabilisation temperature measured with a $744 \mathrm{pH}$ meter (Metrohm). With the exception of the MLSS, VSS, sulphide and feed COD, all analyses were carried out on filtered samples (Whatman \#1). The COD samples were pretreated to eliminate the sulphide contribution to the COD concentration.

\section{Results and discussion}

\section{Sulphate removal/sulphide production}

\section{Operating the CSIRosure pilot plant reactor for bio- logical sulphate removal}

Sulphate reduction was obtained during the operation of the demonstration plant. When the hydraulic retention time (HRT) was $5.1 \mathrm{~h}$, the $\mathrm{SO}_{4}$ removal rate was $12 \mathrm{~g} \mathrm{SO}_{4} / \ell \cdot \mathrm{d}$. The sulphate reduction $\left(\mathrm{mg} / \ell \mathrm{SO}_{4}\right)$ and the sulphide production (expressed as $\mathrm{mg} / \ell \mathrm{SO}_{4}$ ), measured over a period of 9 months in the continuous reactor, is given in Fig. 3. The graphs in Fig. 3 show the relationship between sulphate removed and sulphide produced in the anaerobic reactor (Eq. (1)). The sulphide concentration in the effluent was stoichiometrically slightly less than the removed sulphate concentration:

$$
2 \mathrm{C}_{2} \mathrm{H}_{5} \mathrm{OH}+\mathrm{SO}_{4}^{2-} \rightarrow 2 \mathrm{CH}_{3} \mathrm{COOH}+\mathrm{S}^{2-}+2 \mathrm{H}_{2} \mathrm{O}
$$

The fact that slightly less sulphide was produced than sulphate reduced, as shown in Fig. 3 can be ascribed to the biological sulphide oxidation to sulphur, due to air diffusion on top of the clarifier, which showed a white layer of produced sulphur (Eq. (2)).

$$
\mathrm{H}_{2} \mathrm{~S}+2 \mathrm{O}_{2} \rightarrow \mathrm{S}+\mathrm{H}_{2} \mathrm{O}
$$

Moreover, metal sulphide precipitation occurred due to the metals concentration in the AMD (Eq. (3)):

$$
\mathrm{Me}+\mathrm{S} \rightarrow \mathrm{MeS} \downarrow
$$

During continuous sulphate reduction, high levels of sulphide, often higher than $600 \mathrm{mg} / \ell$, were produced (Fig. 3). At these high sulphide concentrations, sulphate removal continued, indicating that the SRB could proceed with sulphate removal despite the high sulphide concentration in the reactor. This 
result is contrary to the findings of McCartney and Oleskiewicz (1991; 1993), Postgate (1984), Klemps et al. (1985), Shimada (1987), Hilton and Oleszkiewicz, (1988) and Okabe et al. (1992) who found that sulphate reduction could not continue, due to sulphide concentrations higher than at the most $500 \mathrm{mg} / \ell$ (as $\mathrm{S}$ ). However, most of those studies were operated at a reactor $\mathrm{pH}$ of 6.5 to 7.0, whereas the reactor $\mathrm{pH}$ in this study was maintained at an average $\mathrm{pH}$ of 7.5 (Fig. 4). Sulphide toxicity is strongly dependent on $\mathrm{pH}$, because the chemical equilibrium of sulphide is $\mathrm{pH}$ dependent. At $\mathrm{pH} 8$ most of the total sulphide is in the HS- form. Molecular $\mathrm{H}_{2} \mathrm{~S}(\mathrm{~g})$ has been found to be the major toxic form of sulphide because $\mathrm{H}_{2} \mathrm{~S}$ (g) can pass through the lipid cell membrane into the cytoplasm (Speece, 1996). The exact sulphide inhibition mechanisms have not been explained yet. Many studies have been dedicated to sulphide toxicity on sulphate reduction. The results of these toxicity studies have been described by several researchers and have been listed in Table 5 (adopted from Lens et al., 1998). In general, these studies demonstrated that, under mesophilic conditions, both granular and suspended sludge are more resistant to sulphide inhibition at a higher $\mathrm{pH}$ of around 8. This finding can be ascribed to the fact that sulphide is dominant at $\mathrm{pH}$ of 6.5. It was also shown that the sludge was more sensitive to the concentration of $\mathrm{H}_{2} \mathrm{~S}(\mathrm{~g})$ than to the concentration of total sulphide (TS). Weast (1981) described that the $\mathrm{pK}$ value of the dissociation equilibrium of $\mathrm{H}_{2} \mathrm{~S}$ is about 7.04 at $18{ }^{\circ} \mathrm{C}$. Above $\mathrm{pH} 8.0$ to 9.0 virtually all dissolved sulphide is present in its ionised form, while at neutral $\mathrm{pH}$ values 20 to $50 \%$ of the dissolved sulphide is present as $\mathrm{H}_{2} \mathrm{~S}(\mathrm{~g})$, depending on the reactor temperature (O'Flaherty and Colleran, 2000).

\section{Operating the venturi reactor using hydrogen gas as the energy source}

Figure 5 shows the average sulphate removal when the initial sulphide concentrations in the feed water were 0,100 and $268 \mathrm{mg} / \ell$, while Table 6 shows the overall results of the three experiments.

It can be seen (Table 6) that the maximum sulphate removal (1 475
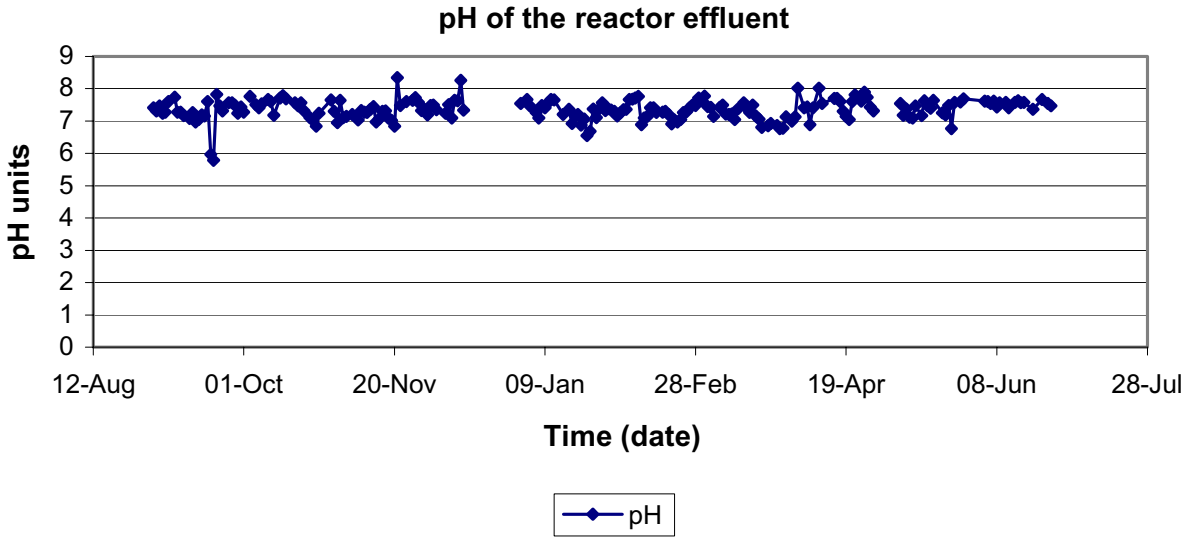

Figure 4

The $\mathrm{pH}$ in the reactor effluent

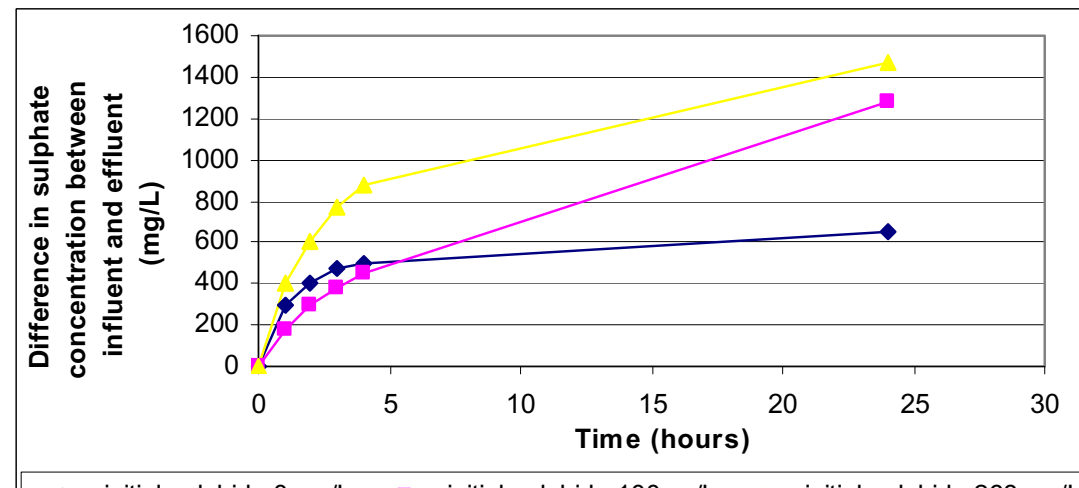

$\multimap$ initial sulphide $0 \mathrm{mg} / \mathrm{L} \longrightarrow$ - initial sulphide $100 \mathrm{mg} / \mathrm{L} \longrightarrow$ initial sulphide $268 \mathrm{mg} / \mathrm{L}$

Figure 5

The average sulphate removal operating the venturi reactor at three different initial sulphide concentrations $(0,100$ and $268 \mathrm{mg} / \mathrm{l})$

\section{TABLE 5}

Un-ionised sulphide $\left(\mathrm{H}_{2} \mathrm{~S}\right)$ and total sulphide (TS) concentration causing a $50 \%$ inhibition on the biological sulphate reduction process

\begin{tabular}{|c|c|c|c|c|c|c|}
\hline Sludge type & Substrate & $\mathrm{T}\left({ }^{\circ} \mathrm{C}\right)$ & $\mathrm{pH}$ & $\begin{array}{c}\mathrm{H}_{2} \mathrm{~S} \\
(\mathrm{mg} / \mathrm{l})\end{array}$ & $\begin{array}{c}\text { TS } \\
(\mathrm{mg} / \mathrm{l})\end{array}$ & Reference \\
\hline $\begin{array}{l}\text { Desulfovibrio } \\
\text { desulfuricans }\end{array}$ & Lactate & 35 & 7.0 & 250 & 500 & Okabe et al.(1992) \\
\hline Sludge susp. & $\begin{array}{l}\text { Lactate/ } \\
\text { Acetate }\end{array}$ & 35 & $7.2-7.6$ & NR & 83 & $\begin{array}{l}\text { McCartney and } \\
\text { Oleszkiewicz (1991) }\end{array}$ \\
\hline Sludge susp. & Lactate & 35 & 7.0 & $>300$ & NR & $\begin{array}{l}\text { McCartney and } \\
\text { Oleszkiewicz (1993) }\end{array}$ \\
\hline Sludge granules & Acetate & 30 & $7.0-7.4$ & 171 & 615 & Visser et al. (1996) \\
\hline
\end{tabular}

* sludge susp. $=$ sludge suspension $* * \mathrm{NR}=$ Not reported

$\mathrm{mg} / \ell$ ) was obtained when the initial feed sulphide concentration was $268 \mathrm{mg} / \ell$, which increased to $500 \mathrm{mg} / \ell$ after $24 \mathrm{~h}$ of batch operation. Similar results could be observed from the study in which the initial sulphide concentration was $100 \mathrm{mg} / \ell$, resulting in the maximum sulphate removal of $1275 \mathrm{mg} / \ell$ and the final sulphide concentration of $452 \mathrm{mg} / \ell$. When no sulphide was added to the feed water, the maximum sulphate removal was only half the amount $(650 \mathrm{mg} / \ell)$ of the results in the studies when sulphide was added to the feed water. These results show that due to the addition of sulphide to the feed water, the sulphate removal rate increased. When calculating the sulphide produced $/$ sulphate $_{\text {removed }}$ ratio, it can be seen from the data in Table 6 that when 0,100 and $268 \mathrm{mg} / \ell$ sulphide was added to the feed, this ratio varied from 0.36 to 0.27 and 0.16 , respectively, while the theoretical value is $0.33\left(\mathrm{~S}^{2-} / \mathrm{SO}_{4}=\right.$ 0.33 ). It can be hypothesised that due to the increased sulphide concentration in the feed, improved sulphate reduction occurred resulting in the formation of intermediate products, such 


\begin{tabular}{|l|l|l|l|}
\hline \multicolumn{5}{|c|}{ TABLE $\mathbf{6}$} \\
The results obtained from the sulphide experiments
\end{tabular}

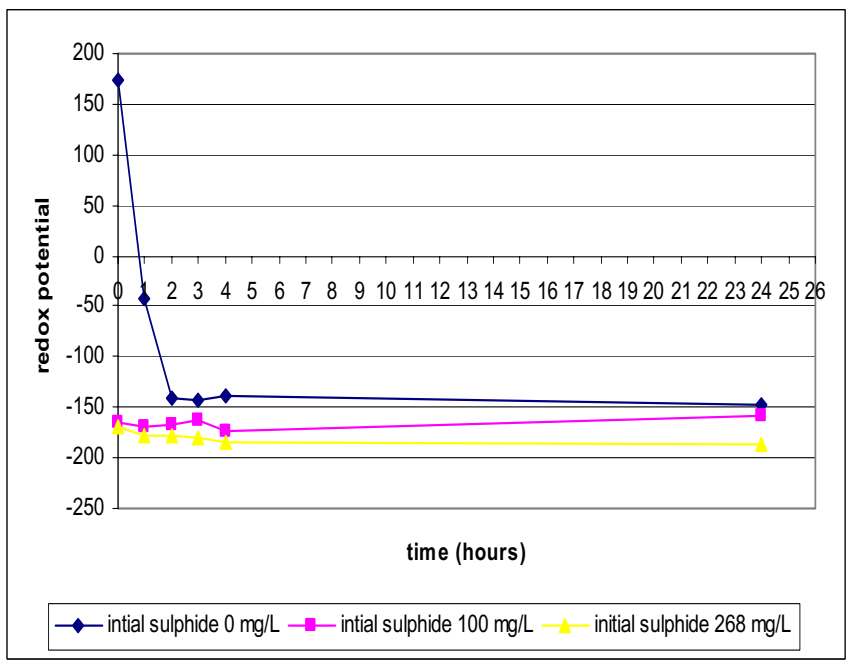

Figure 6

Effect of initial sulphide concentration on redox

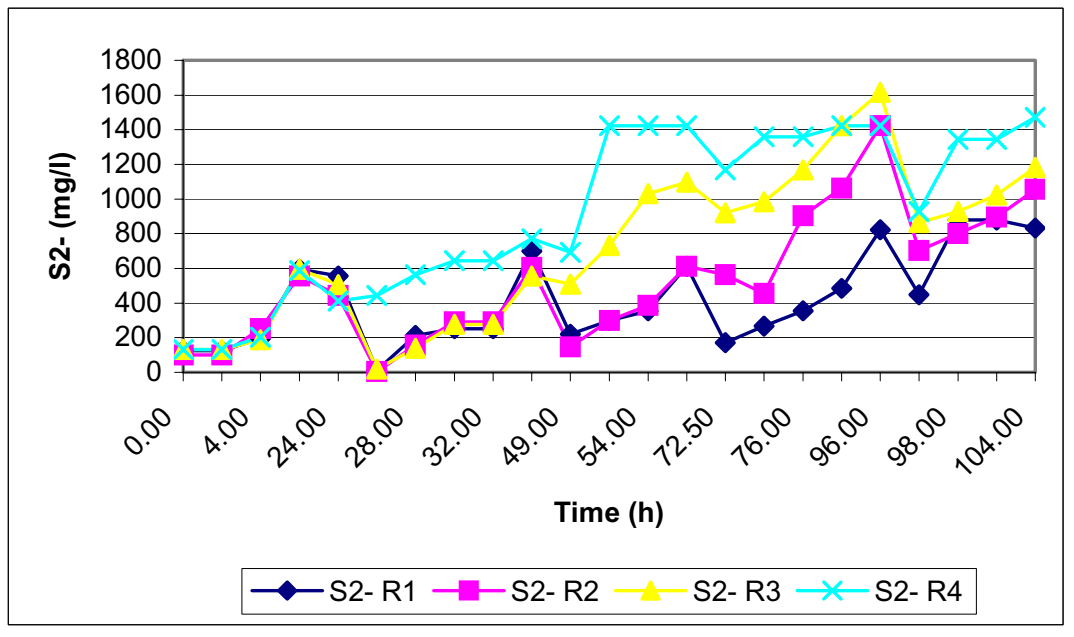

Figure 7

The sulphide concentration in Reactors 1 to 4

a thiosulphate and sulphite, rather than $\mathrm{H}_{2} \mathrm{~S}$. The reduction of $\mathrm{SO}_{4}^{2-}$ to $\mathrm{H}_{2} \mathrm{~S}$ proceeds through a number of intermediate stages (Brock, 1997). The data in Table 6 show that during the three experiments the reactor $\mathrm{pH}$ increased and that the redox potential decreased (Fig. 6). These results show that improved sulphate reduction is obtained when the reactor sulphide concentration and $\mathrm{pH}$ increased and when the redox potential decreased in the reactor. As mentioned before, a reactor $\mathrm{pH}>7.5$ causes a significant reduction of the dissolved $\mathrm{H}_{2} \mathrm{~S}$ concentration and results in a shift toward the dissociated HS- ion.

\section{Operating four stirred reactors under batch} conditions

The sulphide concentrations in reactors $\mathrm{R} 1$ to 4 are given in Fig. 7. It can be seen that the sulphide concentration on Day 1 was the same in all 4 reactors, but that from Day 2 it started to increase in Reactor R4. After Day 2, it increased in both R4 and R3, where after (Days 4 and 5) it increased in R2 and R1 as well. After the Day 3 ( $72 \mathrm{~h}$ ), it had increased in all four reactors, with a maximum at $96 \mathrm{~h}(4 \mathrm{~d})$, when the sulphide concentrations were $1424,1616,1424$ and $824 \mathrm{mg} / \ell$, in R4 to $\mathrm{R} 1$, respectively. At time $98 \mathrm{~h}$, all reactors showed an initial decrease in the sulphide concentration, but during the course of Day 5 , the concentration increased again. The decrease in the sulphide concentration can possibly be ascribed to the fact that the reactor bottles were opened at the top and that air entered the reactor flasks, causing biological sulphide oxidation. Some sulphur-forming could be observed at the top of the reactors.

The volumetric and specific sulphate reduction rates were calculated, which are given in Table 7. The results show that the specific $\mathrm{SO}_{4}$ reduction rates increased from 0.61 to 0.99 to $1.49 \mathrm{~g} \mathrm{SO}_{4} / \mathrm{gVSS}$, when the sulphide concentration increased from 132 to 644 to $1424 \mathrm{mg} / \ell$ in R4. Similar results were obtained in the other three reactors: when the sulphide concentration increased, the sulphate reduction rates increased. It can be observed that the high sulphide concentrations did not inhibit the sulphate reduction rates, but on the contrary seemed to stimulate the sulphate reduction rates. This observation is contrary to the findings of Reis et al. (1992); however, they maintained their reactors at a $\mathrm{pH}$ of 6.2 to 6.4 . It can be speculated that at the operating reactor temperature of 20 to $25^{\circ} \mathrm{C}$ and at a reactor $\mathrm{pH}$ of approximately 8 , the methanogenic bacteria (MB) were inhibited by the higher sulphide concentrations, thus providing the SRB with an opportunity to utilise the available substrate. It has also been reported (Lens and Hulshoff Pol, 2000) that using sulphate-adapted biomass will favour the substrate utilisation by SRB over MB as was the case in this study. Visser (1995) showed that the substrate utilisation rate increased at higher sulphide concentrations, showing that growth and activity of the SRB were uncoupled. The study of Okabe et al. (1992) showed that when the sulphide concentration increased, the cell size of the SRB (Desulfovibrio desulfuricans) decreased, which can partly explain the decreased cell yield at increasing sulphide concentrations during the batch study, namely, when the sulphide concentration increased, the VSS concentration decreased (Table 4). The VSS concentration decrease likely caused the decrease in the sulphate reduction rates as shown in Tables 4 and 7. 


\begin{tabular}{|c|c|c|c|c|c|c|c|c|}
\hline \multicolumn{9}{|c|}{$\begin{array}{l}\text { TABLE } 7 \\
\text { The volumetric and specific } \mathrm{SO}_{4} \text { reduction rates obtained from the batch-test results }\end{array}$} \\
\hline \multirow[b]{2}{*}{ Day } & \multicolumn{2}{|c|}{ R 1} & \multicolumn{2}{|c|}{ R 2} & \multicolumn{2}{|c|}{ R 3} & \multicolumn{2}{|c|}{ R 4} \\
\hline & $\begin{array}{l}\text { Vol R.R* } \\
\mathrm{g} \mathrm{SO}_{4} / \ell\end{array}$ & $\begin{array}{l}\text { Spec. } R . R^{* *} \\
\text { g SO} \\
4 \text { gVSS }\end{array}$ & $\begin{array}{l}\text { Vol R.R } \text { R }^{*} \\
\mathrm{~g} \mathrm{SO}_{4} / \ell\end{array}$ & $\begin{array}{l}\text { Spec. } R . R^{* *} \\
\text { g SO}{ }_{4} / g V S S\end{array}$ & $\begin{array}{l}\text { Vol R.R* } \\
\text { g SO }_{4} / \ell\end{array}$ & $\begin{array}{l}\text { Spec. R.R** } \\
\text { g SO } / \text { /gVSS }\end{array}$ & $\begin{array}{l}\text { Vol R.R } \\
\mathrm{g} \mathrm{SO}_{4} / l^{*}\end{array}$ & $\begin{array}{l}\text { Spec. } R . R^{* *} \\
\text { g SO } / \text { /gVSS }\end{array}$ \\
\hline 1 & 2.26 & 0.56 & 1.94 & 0.59 & 1.92 & 0.47 & 2.30 & 0.61 \\
\hline 2 & 2.64 & 0.54 & 2.64 & 0.5 & 2.52 & 0.49 & 3.36 & 0.99 \\
\hline 3 & 2.40 & 0.35 & 2.40 & 0.43 & 4.68 & 1.01 & 4.87 & 1.49 \\
\hline 4 & 2.86 & 0.37 & 3.43 & 0.76 & 2.64 & 0.72 & 3.07 & 1.05 \\
\hline 5 & 3.82 & 0.78 & 3.12 & 1.17 & 2.64 & 0.97 & 2.62 & 1.13 \\
\hline
\end{tabular}

\section{The treatment of sulphide-rich effluents}

Although the production of sulphide after sulphate reduction might enhance the sulphate removal process, sulphide in aqueous and gaseous solution can cause chemical problems, such as corrosion, odour and an increase of the effluent COD, as sulphide oxidises when in contact with air. Several methods have been described to remove sulphide from the effluents, such as the partial biological sulphide oxidation (Buisman, 1989; Janssen, 1996) to elemental sulphur $\left(\mathrm{S}^{\circ}\right)$. This is a relatively inexpensive option, especially when partial sulphide oxidation can be achieved in the same reactor in which the sulphate reduction is accomplished (Maree et al., 1997). Colourless sulphur bacteria (Thiobacillus spp.) oxidise sulphide to $\mathrm{S}^{\circ}$ or to sulphate in the presence of air $\left(\mathrm{O}_{2}\right)$. Chemically, sulphide can be removed through stripping with $\mathrm{CO}_{2}$ gas, after which the gas mixture is absorbed with a ferric $\left(\mathrm{Fe}^{3+}\right)$ solution, producing $\mathrm{Fe}^{2+}$ and elemental sulphur (Maree et al.,2004) The produced $\mathrm{Fe}^{2+}$ can be oxidised to $\mathrm{Fe}^{3+}$ to maintain the reaction.

\section{Results summarised}

The results of the studies operating the continuous reactor, the venturi reactor as well as the batch-test reactors indicated that high sulphide concentrations (varying from 500 to $1500 \mathrm{TS}$ $\mathrm{mg} / \ell$ ) in an anaerobic sulphidogenic bioreactor, operating at a reactor $\mathrm{pH}$ range of 7.5 to 8.5 and a temperature range of 20 to $25^{\circ} \mathrm{C}$ did not inhibit the sulphate reduction rates. When the sulphide concentration was $700 \mathrm{mg} / \ell$ in the continuous reactor, the sulphate reduction rate was $12 \mathrm{~g} \mathrm{SO}_{4} / \ell \cdot \mathrm{d}$. It was shown that when sulphide was added to the reactor feed water (100 and $268 \mathrm{mg} / \ell$, respectively), operating a tall venture reactor, using hydrogen as the energy source, the maximal sulphate removal was 1275 and $1475 \mathrm{mg} / \ell$, while when no sulphide was added to the feed water, the maximal sulphate removal was $650 \mathrm{mg}$ / $\ell$. The results of the batch tests showed that when the sulphide concentration in the bio reactor increased, the sulphate reduction rate increased as well. When the sulphide concentration was $1400 \mathrm{mg} / \ell$ in the batch test, the volumetric and specific sulphate reduction rates were $4.9 \mathrm{~g} \mathrm{SO}_{4} / \ell \cdot \mathrm{d}$ and $1.5 \mathrm{~g} \mathrm{SO}_{4} / \mathrm{g} \mathrm{VSS}$, respectively. It was speculated that the high sulphide concentration resulted in failure of the MB performance, thus favouring SRB for the substrate competition. The increased sulphate reduction rates observed when the sulphide concentrations increased may be due to an increased thermodynamic driving force for sulphate reduction because of the low redox potential in the reactor. However, the apparent increase in sulphate reduction subsequently as sulphide concentrations increased may not be because of increased thermodynamic driving force. This is because the system is closer to equilibrium position. This relative "distance" from the equilibrium position is not likely to change because an increase in $\mathrm{pH}$ is theoretically expected to result in a decrease in redox potential when a dominant redox couple, like sulphate: sulphide is present. This might suggest that the reason for increased sulphate reduction is more a kinetic than a thermodynamic one. Since the results of the studies described in this paper are based on observations, further research needs to be conducted to better understand the exact mechanisms why the produced sulphide at a reactor $\mathrm{pH}>7.5$ is stimulatory for the biological sulphate reduction.

\section{Conclusions}

When operating three different reactor configurations, applying the biological sulphate reduction technology, the produced sulphide did not inhibit the biological sulphate removal process. Operating a complete mixed pilot scale reactor resulted in a sulphate removal of $12 \mathrm{gSO}_{4} /(\ell . \mathrm{d})$, while the average sulphide production was $600 \mathrm{mg} / \ell$. Under batch test operation, the increased sulphide concentration $(132,644$ and $1424 \mathrm{mg} / \ell$ ) resulted in improved specific sulphate removal rates $(0.61,0.99$ and 1.49 gSO4/gVSS). When operating the Column Venturi reactor and sulphide was added to the feed water (100 and $368 \mathrm{mg} / \ell \mathrm{Na}_{2} \mathrm{~S}$ ), the sulphate removal was 1275 and $1475 \mathrm{mg} / \ell$, respectively. This compared favourably with the sulphate removal of $650 \mathrm{mg} /$ $\ell$, when no sulphide was added to the feed water. The following trend was observed: good sulphate reduction resulted in high sulphide and alkalinity production, which caused a substantial increase in the reactor $\mathrm{pH}$. When operating the column reactor a decrease in the reactor redox potential was observed. The high concentration of sulphide can be removed by the biological sulphide oxidation process or by the chemical stripping technology. In both cases elemental sulphur is the end product.

\section{References}

BUISMAN CJN (1989) Biotechnological Sulphide Removal with Oxygen. Ph.D. Thesis. Agricultural University, Wageningen, The Netherlands.

BROCK, MADIGAN MT, MARTINKO JM and PARKER J (1997) Biology of Microorganisms (8th edn.). Prentice-Hall, Inc.

GREBEN HA, BOLOGO H and MAREE JP (2002) The effect of different parameters on the biological volumetric and specific sulphate removal rates. WISA Bienn. Conf. Water SA Special Edn. 33-37.

HILTON BL and OLESZKIEWICZ JA (1988) Sulphide-induced inhibition of anaerobic digestion. J. Environ. Eng. 1141277.

JANSSEN AJH (1996) Formation and Colloidal Behaviour of Elemental Sulphur Produced from the Biological Oxidation of Hydrogen Sulphide. Ph.D. Thesis. Agricultural University, Wageningen, The Netherlands.

KLEMPS R, CYPIONIKA H, WIDDEL F and PFENNING N (1985) Growth with hydrogen and further physiological characteristics of Desulfotmaculum species. Arch. Microbiol. 143 203-208. 
KOSTER IW, RINZEMA A, DE VEGT AL and LETTINGA G (1986) Sulphide inhibition of the methanogenic activity of granular sludge at various pH levels. Water Res. 20 (12) 1561-1567.

LENS PNL, VISSER A, JANSSEN AJH, HULSHOFF POL LW and LETTINGA G (1998) Biotechnological treatment of sulphate-rich wastewaters. Crit. Rev. Environ. Sci. Technol. 28 (1) 41-88.

LENS PNL and HULSHOFF POL L (ed.) (2000) Environmental Technologies to treat Sulfur Pollution. Principles and Engineering. IWA Publishing, Alliance House, 12 Caxton Street, London SW1H0QS, UK.

MAREE JP, DILL S, VAN TONDER D, GREBEN HA, ENGELBRECHT C, KEHLENBECK M, BESTER C, ADLEM C, STRYDOM W and DE BEER M (1997) Removal of Nitrate, Ammonia and Sulphate from AECI Effluent. Internal CSIR Report No ENV/P/C 97141/ 1.

MAREE JP, STROBOS G, GREBEN HA, NETSHIDAULU E, STEYN E, CHRISTIE A, GUNTHER P and WAANDERS FB (2004) Treatment of acid leachate from coal discard using calcium carbonate and biological sulphate removal. Mine Water and the Environ. 23 (3)

McCARTNEY DM and OLESZKIEWICZ JA (1991) Sulphide inhibition of anaerobic degradation of lactate and acetate. Water Res. 25 203-209.

McCARTNEY DM and OLESZKIEWICZ JA (1993) Competition between methanogens and sulphate reducers: effect of COD: Sulphate ratio and acclimation. Water Environ. Res. 65 655-664.

O'FLAHERTY V and COLLERAN E (2000) Environmental Technologies to treat sulphur pollution. Principles and Engineering. (Lens PNL and Hulshoff Pol L (eds.) IWA, London.
OKABE S, NIELSEN PH and CHARACKLIS WG (1992) Factors affecting microbial sulphate reduction under anaerobic conditions. Appl. Environ. Microbiol. 53 27-32.

OKABE S, NIELSEN PH, JONES WL and CHARACKLIS WG (1995) Sulphide product inhibition of desulfovibrio desulfuricans in Batch and continuous cultures. Water Res. 29 (2) 571-578.

PARKIN GF, LYNCH NA, KUO WC, VAN KEUREN EL and BHATTACHARYA SK (1990) Interaction between sulfate reducers and methanogens fed acetate and propionate Res. J. Water Pollut. Control Fed. 62780.

POSTGATE JR (1984) The Sulphate-Reducing Bacteria (2nd edn.). Cambridge University Press. Cambridge.

REIS MAM, LEMOS PC, ALMEIDA JS and CARRONDO MJT (1992) Evidence for the intrinsic toxicity of $\mathrm{H}_{2} \mathrm{~S}$ to sulphate reducing bacteria. Appl. Microbiol. Biotechnol. 36 145-147.

SHIMADA K (1987) Removal of heavy metals from mine wastewater using sulfate reducing bacteria. J. Water Waste Jpn. 31 (5) 52-56.

SPEECE RE (1996) Anaerobic Biotechnology for Industrial Wastewaters. Archae Press. Nashville, Tennessee.

STANDARDS METHODS (1985) Standard Methods for the Examination of Water and Wastewater $\left(16^{\text {th }} \mathrm{edn}\right.$.) APHA Washington DC.

VISSER A (1995) The Anaerobic Treatment Of Sulphate Containing Wastewater. Ph.D. Thesis, Wageningen Agricultural University, Wageningen, The Netherlands.

WEAST RC (1981) Handbook of Chemistry and Physics (62th edn.). CRC Press Inc., Boca Raton, USA. 